\title{
CEU
}

Instituto Universitario

de Estudios Europeos

Universidad San Pablo

Documento de Trabajo Serie Unión Europea

Número 40 / 2011

Back to Square One-the Past,

Present and Future of the Simmenthal Mandate

Siniša Rodin 
Documento de Trabajo Serie Unión Europea

Número 40 / 2011

\title{
Back to Square One - Past, Present and Future of the Simmenthal Mandate*
}

\author{
Siniša Rodin
}

This paper is part of the book Europe's Constitutional Challenges in the Light of the Recent Case Law-Lisbon and Beyond, edited by I. Pernice and J.M. Beneyto, Baden-Baden, 
El Instituto Universitario de Estudios Europeos de la Universidad CEU San Pablo, Centro Europeo de Excelencia Jean Monnet, es un centro de investigación especializado en la integración europea y otros aspectos de las relaciones internacionales.

Los Documentos de Trabajo dan a conocer los proyectos de investigación originales realizados por los investigadores asociados del Instituto Universitario en los ámbitos histórico-cultural, jurídico-político y socioeconómico de la Unión Europea.

Las opiniones y juicios de los autores no son necesariamente compartidos por el Instituto Universitario de Estudios Europeos.

Serie Unión Europea de Documentos de Trabajo del Instituto Universitario de Estudios Europeos

\section{Back to Square One - Past, Present and Future of the Simmenthal Mandate}

Cualquier forma de reproducción, distribución, comunicación pública o transformación de esta obra solo puede ser realizada con la autorización de sus titulares, salvo excepción prevista por la ley. Diríjase a CEDRO (Centro Español de Derechos Reprográficos, www.cedro.org) si necesita fotocopiar o escanear algún fragmento de esta obra.

(C) 2011, Siniša Rodin

(C) 2011, Fundación Universitaria San Pablo CEU

\section{CEU Ediciones}

Julián Romea 18, 28003 Madrid

www.ceuediciones.es

Instituto Universitario de Estudios Europeos

Avda. del Valle 21, 28003 Madrid

www.idee.ceu.es

ISBN: 978-84-92989-69-0

Depósito legal: M-xxxxxxxxx-2011

Maquetación: Servicios Gráficos Kenaf s.l. 


\section{Table of contents}

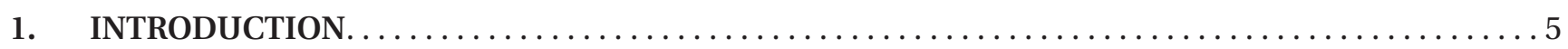

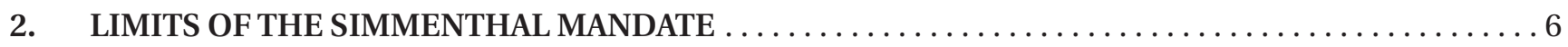

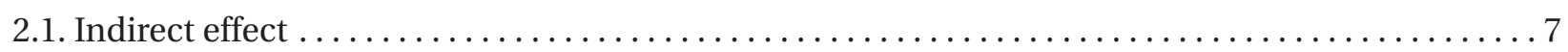

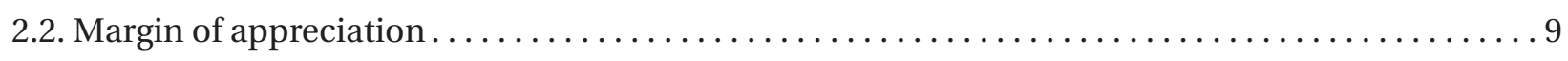

3. SEPARATION OF SIMMENTHAL MANDATE FROM DIRECT EFFECT $\ldots \ldots \ldots \ldots \ldots \ldots \ldots \ldots \ldots$

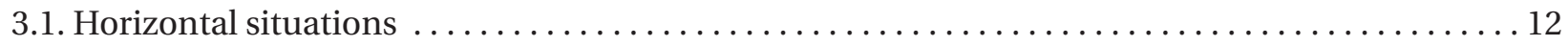

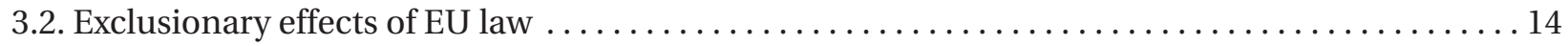

4. SIMMENTHAL AND NATIONAL CONSTITUTIONAL REVIEW $\ldots \ldots \ldots \ldots \ldots \ldots \ldots \ldots \ldots \ldots \ldots$

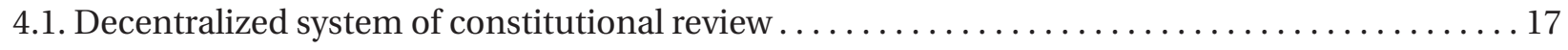

4.2. The constitutional challenge ..................................... 19

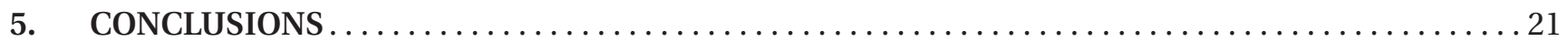





\section{Introduction}

The judgment of the European Court of Justice in case Simmenthal $2^{1}$ belongs to the line of core constitutional cases that defined the process of constitutionalisation of EU law in the 60's and 70's of the XX century. The case is commonly understood as a functional follow-up to the developing doctrine of supremacy of EU law over national laws of the Member States. While in Van Gend en Loos ${ }^{2}$ the Court of Justice established the doctrine of direct effect, in Costa $v$. ENEL $L^{3}$ it expressed its understanding that EU law can not be overridden by subsequent national measures 'however framed', and in Simmenthal 2, it gave answer to the question what are the consequences of the fact that individuals can invoke rules of EU law against the State, such rules having a higher legal force than national legal rules.

The three cases have placed individuals and their individual rights in the centre of the discussion. Unlike in international law, individuals are subjects of the 'new legal order' and enjoy rights which national courts must protect (Van Gend). Such rights obtain regardless any subsequent national regulation (Costa), and 'render automatically inapplicable' any conflicting provision of national law (Simmenthal 2). Accordingly, it is a duty of national courts to set such conflicting rules of national law aside and protect individual rights that are conferred directly by the relevant rule of $\mathrm{EU} \mathrm{law}^{4}$, without requesting or awaiting a prior decision of any other national body having its own discretion, including the national constitutional court ${ }^{5}$.

The last mentioned consequence - the duty of national courts to set aside national rules that stand in way of protection of EU law based on individual rights, without prior recourse to a national constitutional court - has fundamentally affected national systems of judicial review. Instead of a recourse to the national constitutional court, an ordinary judge acquired a mandate to resolve the issue of conflict of national law with EU law herself, possibly with interpretative guidance of the European Court of Justice in preliminary reference procedure. This duty of a national judge will be called the Simmenthal mandate ${ }^{6}$.

Case 106/77 Amministrazione delle Finanze dello Stato v Simmenthal SpA (Simmenthal 2) [1978] ECR 629.

2 Case 26/62 NVAlgemene Transport-en Expeditie Onderneming van Gend \& Loos v Netherlands Inland Revenue Administration [1978] ECR 1, English special edition.

3 Case 6/1964 Flaminio Costa v. E.N.E.L. [1964] ECR 585 English special edition, para 3: ' '... the law stemming from the Treaty, an independent source of law, could not, because of its special and original nature, be overridden by domestic legal provisions, however framed.... In German: '... aus alledem folgt, dass dem vom Vertrag geschaffenen, somit aus einer autonomen Rechtsquelle fließenden Recht wegen dieser seiner Eigenständigkeit keine wie immer gearteten innerstaatlichen Rechtsvorschriften vorgehen können.'

4 Simmenthal 2, above $\mathrm{n}$ 1, para 21: 'Furthermore, in accordance with the principle of the precedence of Community Law, the relationship between provisions of the Treaty and directly applicable measures of the institutions on the one hand and the national law of the Member States on the other is such that those provisions and measures not only by their entry into force render automatically inapplicable any conflicting provision of current national law but - in so far as they are an integral part of, and take precedence in, the legal order applicable in the territory of each of the Member States - also preclude the valid adoption of new national legislative measures to the extent to which they would be incompatible with Community provisions.

5 Simmenthal 2, above n 1, para 24: ‘. . a national court which is called upon, within the limits of its jurisdiction, to apply provisions of Community law is under a duty to give full effect to those provisions, if necessary refusing of its own motion to apply any conflicting provision of national legislation even if adopted subsequently, and it is not necessary for the court to request or await the prior setting aside of such provision by legislative or other constitutional means.'

6 The expression 'Simmenthal mandate' was first introduced by M Claes. See M Claes, The National Courts' Mandate in the European Constitution (Hart Publishing 2006). 
While the doctrine of supremacy has not significantly changed since the '60s of the XX century, and has been upheld by the Treaty of Lisbon 7 , the Simmenthal mandate has undergone an evolution. Today, it cannot longer be understood as a mere procedural prong of supremacy, but as a finely knit web of reflexive cooperation of national courts with the ECJ. In this paper In Chapter 2, I will first describe how the Simmenthal mandate softened, primarily by the development of doctrines of indirect effect and margin of appreciation. Second, in Chapter 3, I will discuss whether the Simmenthal mandate can be separated from the doctrine of direct effect and what are the practical consequences of such separation. Finally, in Chapter 4, I will try to demonstrate how the Simmenthal mandate affected the European judicial dialogue and possibly triggered a revival of national constitutional review.

\section{Limits of the Simmenthal mandate}

The original wording of the Simmenthal 2 judgment immediately rose questions about the effects in national law. One question was whether the judgment, in effect, restricts regulatory powers of national parliaments and the other whether incompatibility with EU law affects the very existence of a national rule, or merely its applicability.

The first question was addressed by the ECJ in 1998, several years following the inauguration of the indirect effect doctrine. The ECJ went to soften the Simmenthal doctrine and clarified that supremacy of Community Law does not restrict regulatory powers of the Member States ${ }^{8}$, and does not affect existence, but only application of a national legal rule ${ }^{9}$. That position is kept until this day as can be seen from the more recent Filipiak judgment ${ }^{10}$. The ECJ confirmed that the duty of a national court to set aside rules of national law incompatible with EU law does not depend on and is not affected by jurisdiction of a national constitutional court to rule on the constitutionality of the same rule.

However, while IN.CO.GE and Filipak represent internal limits to the Simmenthal mandate, doctrines of indirect effect and margin of appreciation impose systemic boundaries. The main proposition that I want to discuss in this Chapter is that the doctrines of indirect effect and margin of appreciation reduced the number of situations in which setting aside of national law was necessary. On the other hand, national judges acquired new responsibilities, namely to interpret national law in light of EU law and to enforce national margin of appreciation within the limits imposed by the Treaty ${ }^{11}$ and being aware of the supervision exercised by the ECJ.

\footnotetext{
7 The position of the ECJ is confirmed by the Declaration 17 Concerning Primacy to the Lisbon Treaty and the Opinion of the Council Legal Service: 'The Conference recalls that, in accordance with well settled case law of the EU Court of Justice, the Treaties and the law adopted by the Union on the basis of the Treaties have primacy over the law of Member States, under the conditions laid down by the said case law. The Conference has also decided to attach as an Annex to this Final Act the Opinion of the Council Legal Service on the primacy of EC law as set out in 11197/07 (JUR 260): "Opinion of the Council Legal Service of 22 June 2007: It results from the case-law of the Court of Justice that primacy of EC law is a cornerstone principle of Community law. According to the Court, this principle is inherent to the specific nature of the European Community. At the time of the first judgment of this established case law (Costa/ENEL,15 July 1964, Case 6/6411) there was no mention of primacy in the treaty. It is still the case today. The fact that the principle of primacy will not be included in the future treaty shall not in any way change the existence of the principle and the existing case-law of the Court of Justice."' Joined cases C-10/97 to C-22/97 Ministero delle Finanze v IN.CO.GE. '90 Srl [1998] ECR I-06307, para 20.

9 IN.CO.GE., above n 8, para 21: 'It cannot therefore, contrary to the Commission's contention, be inferred from the judgment in Simmenthal that the incompatibility with Community law of a subsequently adopted rule of national law has the effect of rendering that rule of national law non-existent. Faced with such a situation, the national court is, however, obliged to disapply that rule, provided always that this obligation does not restrict the power of the competent national courts to apply, from among the various procedures available under national law, those which are appropriate for protecting the individual rights conferred by Community law'; see also I Pernice, 'Costa v ENEL and Simmenthal: Primacy of European Law' in M P Maduro and L Azoulai (eds.), The Past and Future of EU Law (Oxford 2010) 47, 58.

10 Case C-314/08 Krzysztof Filipiak v Dyrektor Izby Skarbowej w Poznaniu [2009] ECR 0000, para 84.

11 Case C-36/02 Omega Spielhallen- und Automatenaufstellungs-GmbH v Oberbürgermeisterin der Bundesstadt Bonn [2004] ECR 9609, para 31.
} 


\subsection{Indirect effect}

Doctrine of indirect effect, as developed by the ECJ, establishes an obligation for national courts to interpret national law in line with law of the EU. The doctrine has its origin in the international law principle pacta sunt servanda. Arguably, the doctrine also has its roots in national legal doctrines of interpretation of national law in accordance with international law, such as the German doctrine of völkerrechtsfreundliche Auslegung or Lord Denning's doctrine in Macarthys v. Smith ${ }^{12}$. Both doctrines assume that it was not intention of the legislature to contravene international commitments and for that reason national rules have to be interpreted, as far as possible, in accordance with them.

The doctrine of indirect effect is based on similar assumptions. According to the doctrine, national law has to be interpreted, as far as possible, in accordance with EU law. The doctrine is justified by the duty of loyal cooperation (after Lisbon - sincere cooperation), laid down by what used to be Article 5 of the Treaty establishing the European Economic Community, later on Article 10 of the Treaty establishing the European Community and today Article 4(3) TEU.

The doctrine of indirect effect, was clarified by the ECJ in Von Colson and Kamman ${ }^{13}$. The obligation arising under original Article 5 of the Treaty, to interpret national law in such a way as to achieve result envisaged by a directive '.. is binding on all the authorities of Member States, including, for matters within their jurisdiction, the courts.'

While the language of the ECJ was restricted to directives, there is no doubt that duty of cooperation applies to all obligations under the Treaties. This is even more clear after Article 4(3) of the Treaty of Lisbon re-phrased Article 10 EC and now refers to the '... tasks which flow from the Treaties' instead of the earlier one which referred to the 'tasks arising from fulfillment of Treaty obligations'. Chalmers, Davies and Monti consider the new phrase more open-ended and reaching even beyond Treaty obligations ${ }^{14}$. This is also confirmed by more recent case law of the ECJ which speaks more broadly about an obligation to interpret national law in conformity with Community law ${ }^{15}$.

The doctrine of indirect effect, made the Simmenthal mandate a subsidiary obligation. It follows from the very logic of judicial deliberation that a national judge deciding a case, will first have to interpret national law, as far as possible, in accordance with law of the EU, and only if that is not possible, will have an obligation to set the national legal rule aside. The ECJ adopted a standing case law according to which it is for the national court to interpret and apply national law in conformity with the requirements of EU law, and where such application is not possible, the national court must apply EU law ' ... in its entirety and protect rights which the latter confers on individuals, disapplying, if necessary, any contrary provision of domestic law ${ }^{16}$.'

12 'If the time should come when our Parliament deliberately passes an Act - with the intention of repudiating the Treaty or any provision in it - or intentionally of acting inconsistently with it - and say so in express terms - then I should have thought that it would be the duty of our courts to follow the statute of our Parliament ... Unless there is such an intentional and express repudiation of the Treaty, it is our duty to give priority to the Treaty.' Macarthys Ltd $v$ Smith [1979] 3 All ER 325.

13 Case 14/83 Sabine von Colson and Elisabeth Kamann v Land Nordrhein-Westfalen [1984] ECR 1891, para 26. See also Case C-106/89 Marleasing [1990] ECR I-4135, para 8; Case C-81/82 Paola Faccini Dori v Recreb [1994] ECR I-3325, para 26 ; Case C-129/96 Inter-Environnement Wallonie [1997] ECR I-7411, para 40; joined cases C-397/01 to C-403/01 Bernhard Pfeiffer, Wilhelm Roith, Albert Süß, Michael Winter, Klaus Nestvogel, Roswitha Zeller and Matthias Döbele v Deutsches Rotes Kreuz, Kreisverband Waldshut eV, para 110; and Joined Cases C-378/07 to C-380/07 Angelidaki and Others [2009] ECR I-3071, para 106.

14 D Chalmers, G Davies and G Monti, European Union Law, 2nd edn (Cambridge 2010) 223.

See e.g. Case C-212/04 Adeneler and Others v. ELOG [2006] ECR I-6057, para 113.

16 Case C-208/05 ITC Innovative Technology Center GmbH v Bundesagentur für Arbeit [2007] ECR I-181, paras 68 and 69 ; see also Case 157/86 Murphy and Others [1988] ECR 673, para 11; Case C-262/97 Engelbrecht [2000] ECR I-7321, paras 39 and 40, and Case C-224/97 Ciola [1999] ECR I 2517, para 26. 
This has actually become the main logic in Britain where indirect effect has become 'the main form of ensuring effect of Directives whether correctly incorrectly or not transposed at all ${ }^{17}$ '. Not less importantly, indirect effect has been found to be applied more regularly in Member States '... with a more substantive and active tradition in interpreting their law in consistency with the national constitution ${ }^{18}$.'

In any case, as long as national law can be interpreted as being compatible with the law of the EU, there will be no need for a national court to set it aside for being incompatible with a rule of EU law.

On the other hand, interpretative obligations of national courts have significantly increased power of courts of ordinary jurisdiction in respect of the legislature. Standard meaning of national legal rules, when interpreted in accordance with EU law, may significantly diverge from its standard meaning under national law ${ }^{19}$. In that way ordinary courts, when interpreting national law in EU law friendly way, may come into position to rephrase constitutional principles and concepts (e.g. equality).

The question, however, remains, to what extent the obligation to interpret national law in accordance with EU law and, more generally, the duty of sincere cooperation, binds national constitutional courts when confronted with an issue whether obligations under the Treaties impinge upon national constitutional guarantees. Since national courts, including constitutional courts, may not rule on validity of EU law ${ }^{20}$ the only way to challenge EU law on grounds of national constitution is to declare a national implementing measure unconstitutional. The german Bundesverfassungsgericht has developed a practice according to which national implementing measures are unconstitutional for failing to meet national constitutional standards.

On July, 18, 2005 the Bundesverfassungsgericht invalidated the Europäisches Haftbefehlsgesetz, national legislation implementing the Framework Decision on European Arrest Warrant ${ }^{21}$. The Act was declared unconstitutional for having violated Article 16(2) GG i.e. the principle of legality, and Article 19(4) GG for not having provided for a judicial remedy against an extradition decision ${ }^{22}$. The Bundesverfassungsgericht continued the same practice in the landmark Lisbon decision of June, 30, $2009{ }^{23}$ when it invalidated legislation giving effect to the Lisbon Treaty in Germany ${ }^{24}$.

Declaring national measures implementing EU law unconstitutional is based on dualist understanding of relationship of EU law and national law according to which ECJ interprets EU law and national (constitutional) courts national law ${ }^{25}$. Since ordinary courts have no role to play in abstract constitutional review, the described

17 G Betlem, 'The Docrine of Consistent Interpretation: Managing Legal Uncertainty' (2002) 22 OJLS 387, 399, quoted from Chalmers et al., above n 14, 294.

18 C Backes and M Eliantonio, 'The influence of the ECJ's case law on indirect effect in the Italian, German, Dutch and English administrative legal systems and its application by the national administrative courts' (...) SSRN research paper SSRN-id1427255.

19 See e.g. Case C-105/03 Criminal Proceedings against Maria Pupino [2005] ECR I-5285.

20 Case 314/85 Foto-Frost v Hauptzollamt Lübeck-Ost [1987] ECR 4199, para 17.

21 Council Framework Decision of 13 June 2002 on the European Arrest Warrant and the Surrender Procedures Between Member States [2002] 584 OJ L190/1.

22 See S Mölders, 'European Arrest Warrant Act is Void - The Decision of the German Federal Constitutional Court of 18 July 2005' (2006) 7 German Law Journal 45, 57; for a Hungarian case see Chalmers et al., above n 14, 226. The Hungarian case reported by Chalmers et al. is particularly interesting. The Hungarian Constitutional Court invalidated a piece of national legislation identical to a Regulation on grounds of constitutional prohibition of retroactivity. Technically, according to the judgment of the ECJ in Case 34/73 Fratelli Variola S.p.A. v Amministrazione italiana delle Finanze [1973] ECR 981, since regulations are directly applicable, this decision should not have any effect on the Regulation itself.

23 BVerfG, 2 BvE 2/08 of 30 June 2009.

24 Act of 8 October 2008 on the Treaty of Lisbon of 13 December 2007 (Gesetz vom 8. Oktober 2008 zum Vertrag von Lissabon vom 13. Dezember 2007, Federal Law Gazette Bundesgesetzblatt - BGBl 2008 II, 1038 and Art 1 number 1 and number 2 of the Act Amending the Basic Law (Art 23, 45 and 93) (Gesetz zur Änderung des Grundgesetzes <Artikel 23, 45 und 93>) of 8 October 2008 (Federal Law Gazette Bundesgesetzblatt I, 1926) and Art 1 \$ 3.2, § 4.3 number 3 and $\S 4.6$ as well as $\$ 5$ of the Act Extending and Strengthening the Rights of the Bundestag and the Bundesrat in European Union Matters (Gesetz über die Ausweitung und Stärkung der Rechte des Bundestages und des Bundesrates in Angelegenheiten der Europäischen Union, document of the Bundestag $<$ Bundestags-Drucksache-BTDrucks $>$ 16/8489).

25 D Chalmers, 'A Few Thoughts on the Lisbon Judgment', in A Fischer-Lescano, C Joerges and A Wonka (eds.), The German Constitutional Court's Lisbon Ruling: Legal and Political-Science Perspectives (Bremen, Zentrum für europäische Rechtspolitik 2010) 5, 6. 
practice and authority of the constitutional court's opinions vaccinates national legal order against constitutional conflicts being decided before ordinary courts, thus further narrowing the playground for application of the Simmenthal mandate.

National constitutional principles, however, should not pose an obstacle to full compliance with the Treaties. It is a well-established principle of international law codified by Article 27 of the Vienna Convention on the Law of Treaties, that treaties should be implemented in good faith and that a State may not invoke its national law, not even her constitution in order to excuse non performance of an international legal duty ${ }^{26}$. The same should hold even more in respect of the Founding Treaties which represent the foundation of the "new legal order, more specifically, under the duty of sincere cooperation'. In other words, declaring national measures implementing EU law unconstitutional has to be within the meaning of bona fide implementation of the Treaties, and Member States can not claim their internal 'provisions, practices or circumstances' in order to justify failure to comply with EU law27.

\subsection{Margin of appreciation}

In addition to the 'comply or disapply' mechanism which was described above, the scope of the Simmenthal mandate has been additionally narrowed by the doctrine of margin of appreciation.

The ECJ has allowed margin of discretion since its early case law. The margin has been allowed either to the national legislature, e.g. when implementing directives ${ }^{28}$, or to the national courts when interpreting national law $^{29}$. In either case, the margin is exercised under ultimate supervision of the ECJ.

However, while in cases such as Van Duyn, the margin was attached to a justification (public policy) ${ }^{30}$, and in Orfanopoulos and Pfeiffer to implementation of a directive, the doctrine lived up to its genuine revival as a tool of conflict resolution between national constitutional guarantees and the EU market freedoms.

The origins of the conflict are rooted into the fundamental rights discourse between the ECJ and national constitutional courts ${ }^{31}$ and are abundantly discussed in literature. In essence, the question is the following: If legitimacy of our liberal democratic constitutions depends on respect for protected spheres of fundamental rights that our national governments are not allowed to encroach upon, how can that possibly be allowed to

26 Concerning national constitutional law A de Hoogh draws attention to the drafting history of Art 27 of the Vienna Convention which '...confirms that the reference to internal law comprises the constitution of a State party. In fact, the amendment proposed by Pakistan initially claimed "[e]very treaty in force is binding upon the parties to it and must be performed by them in good faith, and no party may invoke the provisions of its constitution or its laws as an excuse for its failure to perform this duty" (Vienna Conference, Documents, p. 145; adopted: 55 in favor, none against, 30 abstentions (Vienna Conference, First Session, 158)). Though certain hesitations may be observed on the part of the participants in the Vienna Conference in 1968-1969 to support the resulting provision (adopted: 73 in favour, 2 against, 24 abstentions; Vienna Conference, Second Session, 54), as to this particular point, the provision did find favor and only two States (Venezuela and Iran) expressed their opposition suggesting the primacy of their constitutional law over treaties. Two States (Venezuela and Guatemala) specifically attached reservations on this point, against which objections have been raised by certain other States...' A de Hoogh, 'The Relationship between National Law and International Law in the Report of the Georgia Fact-Finding Mission', at www.ejiltalk.org (access: 8 February 2011).

27 In Case C-323/97 Commission v Belgium [1998] ECR I-4281 Belgium pleaded the need to amend her constitution prior to be able to implement a directive. The ECJ did not accept the argument and found Belgium in breach of EU law. See para 8; see also Case C-107/96 Commission v Spain [1997] ECR I-3193, para 10.

28 See e.g. joined cases C-482/01 and C-493/01 Georgios Orfanopoulos and Others and Raffaele Oliveri v Land Baden-Württemberg [2004] ECR 5257, para 114; Case C-271/91 Marshall [1993] ECR I-4367, para 37, and joined cases C-397/01 to C-403/01 Bernhard Pfeiffer, and others, above n 14, para 105.

29 Case C-208/05 ITC Innovative Technology Center GmbH v Bundesagentur für Arbeit [2007] ECR I-181, paras 68 and 69.

30 Case 41/74 Yvonne van Duyn v Home Office [1974] ECR 1337, para 18; see also Case 30/77 Régina v Pierre Bouchereau [1977] ECR 1999, para 34.

31 While the ECJ in Case 11/70 Internationale Handelsgesellschaft mbH v Einfuhr- und Vorratsstelle für Getreide und Futtermittel [1970] ECR 01125, maintains its position originally developed in Costa $v$. ENEL (see above $\mathrm{n} 3$ ), the Bundesverfassungsgericht claims its ultimate competence in fundamental rights cases and supremacy of national constitutional fundamental rights guarantees over Community law. See Case Solange I, BVerfGE 37, 271, 2 BvL 52/71; see also Case Frontini, Sentenza n 183, 18 december 1973. 
the supranational Union. If fundamental rights are guaranteed at all, they should be guaranteed at all levels of governance.

The ultimate argument against unfettered supremacy of Community law over national constitutions was that national legal orders protect fundamental rights better. Accordingly national constitutional guarantees of fundamental rights should prevail over conflicting Community Law. This position brought up by the Bundesverfassungsgericht ${ }^{32}$ and endorsed by Corte Costituzionale ${ }^{33}$ was in clear conflict with the doctrine of supremacy, as developed by the ECJ.

The ECJ reacted to the criticism by incorporating fundamental rights into the legal order of the EU by the judgment in Nold ${ }^{34}$. The incorporation served the purpose and compensated the absence of an EU-law based charter of fundamental rights, to the satisfaction of the Bundesverfassungsgericht $t^{35}$. However, the human rights dialogue between the two courts was primarily based on subsidiarity arguments and the dispute was, in essence, jurisdictional. Inasmuch, the Nold incorporation and the Solange subsidiarity did not address the problem of divergent constitutional values.

Incorporation of fundamental rights into the EU legal order did not change the scope of the Simmenthal mandate. It only added an obligation of national courts, when deciding cases within scope of EU law, to take an additional criterion into account. Since fundamental rights are binding also on the Member States when implementing EU law ${ }^{36}$, national courts still have the obligation to interpret national law accordingly, or to set aside national legal rule. The real problem concerns potentially competing national and European constitutional values.

Such an issue emerged in SPUC v. Grogan ${ }^{37}$ only to be swept under the rug. Confronted with the choice between a national understanding of right to life and free movement of services, the ECJ decided to narrow the scope of EU law in order to avoid invoking supremacy against the Irish constitution. Student association is not an economic operator and thus outside the scope of free movement of services. However, had it been a case of an established company, the conflict would have been inevitable and, as the EU law stood at the time, the Irish court would have had an obligation to set the national constitutional rule aside. It is probably the same concern that led Ireland to insist on the specific protocol to the Maastricht Treaty, granting immunity according to which '... Nothing in the Treaty on European Union, or in the Treaties establishing the European Communities, or in the Treaties or Acts modifying or supplementing those Treaties, shall affect the application in Ireland of Article 40.3.3 of the Constitution of Ireland ${ }^{38}$.'

As far as the Simmenthal mandate is concerned, two things can be learned from Grogan. First, by narrowing the scope of application of EU law the ECJ applied an implied margin of appreciation. National constitutional values escape EU law scrutiny, as long as they are outside scope of EU law. In such situations national courts are relieved from the Simmenthal mandate. Second, the Irish Protocol to the Maastricht Treaty gave Irish courts permanent immunity from obligation to disapply right to life, as defined by the Irish constitution. The Protocol had significance of a constitutional amendment that grants a constitutional, i.e. a Treaty-based

\footnotetext{
Solange I, BVerfGE 37, 271, above n 31; Solange II, BVerfGE 73, 339; Maastricht, BVerfGE 89, 155.

Frontini, above $\mathrm{n} 31$.

Case 4/73 J. Nold, Kohlen- und Baustoffgroßhandlung v Ruhrkohle Aktiengesellschaft [1977] ECR 1, para 13.

Case Solange II, BVerfGE 73, 339, 2 BvR 197/83.

Case 5/88 Hubert Wachaufv Bundesamt für Ernährung und Forstwirtschaft [1989] ECR 02609, para 19.

Case C-159/90 The Society for the Protection of Unborn Children Ireland Ltd v Stephen Grogan and others [1991] ECR 4685.

Protocol annexed to the Treaty on European Union and to the Treaties establishing the European Communities.
} 
margin of appreciation and preempts Simmenthal mandate in future cases which, unlike Grogan, may fall within the scope of EU law.

While deference of the ECJ in Grogan was probably, at least partially, value motivated, the actual case was decided on the grounds of scope of EU law. The real test, however, followed in cases which were undoubtedly within scope of EU law and which involved substantive policy choices between market freedoms and constitutional rights or values.

Today, margin of appreciation has become a standard tool of the ECJ which can be compared to the approach developed in case law of the European Court of Human Rights ${ }^{39}$. It provided the ECJ an elegant way out from having to make policy and value choices that impinge on constitutional values of the Member States. The present approach of the ECJ emerged in Schmidberger ${ }^{40}$ and Omega Spielhallen ${ }^{41}$. In the two cases margin of appreciation was bundled together with a new obligation of national courts, namely, to 'strike a fair balance' between market freedoms and fundamental rights ${ }^{42}$. Where such balance is struck, margin of appreciation will apply and national law will not have to be set aside. National court's judgment is subject to scrutiny of the ECJ which will apply the proportionality test. In that way the national judge is immerged into a fortune-telling exercise with one eye looking into the national legal rules and values and the other into those developed in the case law of the ECJ. Not less importantly, as it was put by the ECJ in Omega, certain national values can co-exist even in absence of their general acceptance, and there is no need for their harmonization ${ }^{43}$.

Messages of Schmidberger and Omega seem to be the following. The Interpretation of national law in accordance with EU law is a dynamic exercise. If the regulatory State can satisfy the court that certain national value (a.) is in balance with one of the Treaty guarantees, or (b.) due to its national importance, is covered by margin of appreciation, a national judge will not have to set such national rule aside.

The path taken by the ECJ in Schmidberger and Omega seems to be valid and well established law ${ }^{44}$. In accordance with that line of reasoning the ECJ restricts the scope of judicial review leaving the Member States larger playground for national regulation, even in case where important national regulatory interests encroach upon area of market freedoms, under the condition that national measures are equally applicable and subject to having passed a proportionality test ${ }^{45}$. In that way the ECJ additionally enforced regulatory autonomy of Member States by limiting the scope for supremacy of Community law in areas where Member States enjoy a margin of discretion. On the other hand, the ECJ enhanced responsibility of Member States for application of Community law by making legality of national measures dependant on non-discrimination and proportionality.

The ECJ has been more generous to grant margin of appreciation in cases involving fundamental rights guarantees and national constitutional values, such as freedom of assembly in Schmidberger or human dignity

39 For the European Human Rights Convention see e.g. H C Yourow, The Margin of Appreciation Doctrine in the Dynamics of the European Court of Human Rights Jurisprudence (London, New York, The Hague, Martinus Nijhoff Publishers, Kluwer Press 1996).

40 Case C-112/00 Eugen Schmidberger, Internationale Transporte und Planzüge v Republik Österreich [2003] ECR I-5659.

41 Omega Spielhallen, above $\mathrm{n} 11$.

42 Schmidberger, above n 40, paras 81 and 82: '81. In those circumstances, the interests involved must be weighed having regard to all the circumstances of the case in order to determine whether a fair balance was struck between those interests. 82. The competent authorities enjoy a wide margin of discretion in that regard. Nevertheless, it is necessary to determine whether the restrictions placed upon intra-Community trade are proportionate in the light of the legitimate objective pursued, namely, in the present case, the protection of fundamental rights.'

43 Omega, above n 11, para 31 : '... the specific circumstances which may justify recourse to the concept of public policy may vary from one country to another and from one era to another. The competent national authorities must therefore be allowed a margin of discretion within the limits imposed by the Treaty.

44 See most recently joined cases C-338/04, C-359/04 and C-360/04 Criminal proceedings against Massimiliano Placanica, Christian Palazzese and Angelo Sorricchio [2007] ECR I-01891, para 47.

45 More on proportionality analysis see in Opinion of Advocate General Maduro in Case C-434/04 Jan-Erik Anders Ahokainen Mati Leppik v Virallinen syyttäjä [2006] ECR I-9171. 
in Omega. It has been less generous in cases involving ordinary national law, even when it comes to well established national principles of civil law. For example, in Traghetti del Mediterraneo ${ }^{46}$, the ECJ found national law excluding State liability for damages for breach of EU law for damage caused to individuals by an infringement attributable to a court adjudicating at last instance, and restricting liability for damages rising from erroneous application of EU law by a national court to cases of intentional fault, serious misconduct and denial of justice is precluded by EU law. In such a case the Simmenthal mandate is fully applicable and the national court has to set the national legal rule aside.

\section{Separation of Simmenthal mandate from direct effect}

The obligation to set aside national legal rules which are contrary to EU law is often understood as a procedural prong of direct effect and supremacy of EU law. Not to forget, the legal issue in Simmenthal 2, as phrased by the ECJ was ' ... what consequences flow from the direct applicability of a provision of Community law in the event of incompatibility with a subsequent legislative provision of a Member State ${ }^{47}$.' What was implicit in the question so framed was that whatever consequences may obtain, they necessarily depend on the rule of EU law being clear, unconditional and precise.

However, gradually, the Simmenthal mandate emancipated itself from direct effect as the ECJ started to recognize exclusionary effects to rules of EU law which are not clear, unconditional and precise. In other words the duty to set aside national law can be understood more broadly and separately from the direct effect context ${ }^{48}$.

The main purpose of this Chapter is to explain how the ECJ separated the duty of national court to set aside EU-incompatible national law from direct effect of EU law. Since significant developments in this field were triggered by efforts of the ECJ to remedy the lack of horizontal direct effect of directives, I will, first, explain how the Simmenthal mandate applies in horizontal situations and proceed with the discussion of exclusionary effects of EU law.

\subsection{Horizontal situations}

Doctrines of direct effect and supremacy were originally developed in vertical situations, i.e. in legal relationships between individuals and the State. It did not, however, take long before the ECJ extended them to horizontal situations, at least, as far as the Treaties were concerned ${ }^{49}$.

Judgment in Simmenthal 2, never made a distinction between vertical and horizontal situations, despite of the fact that horizontal direct effect of the Treaties has already been recognized at the time when the

46 Case C-173/03 Traghetti del Mediterraneo SpA v Repubblica italiana [2006] ECR I-5177, para 46.

47 Simmenthal 2, above n 1, para 13.

48 M Dougan, 'When Worlds Collide! Competing Visions of the Relationship Between Direct Effect and Supremacy’ (2007) 44 Common.Mkt.L.Rev. 931, 934: ‘.. direct effect encompasses not only the creation and enforcement of subjective individual rights, but any situation in which Community norms produce independent effects within the national legal systems.'

49 Case 36/74 Walrave and L.J.N. Koch v Association Union cycliste internationale, Koninklijke Nederlandsche Wielren Unie and Federación Española Ciclismo [1974] ECR 1405; Case 43/75 Gabrielle Defrenne v Société anonyme belge de navigation aérienne Sabena [1976] ECR 455. 
judgment was delivered ${ }^{50}$. Implicitly, it seems to be beyond doubt, that the Simmenthal mandate is applicable in both situations. This conclusion follows also from the judgment in Walrave and Koch where the ECJ stated that '... by reason of the fact that it is imperative, the rule on non-discrimination (on grounds of nationality, S.R.) applies in judging all legal relationships ${ }^{51}$.' This phrase leaves very little discretion to the national court but to ensure full effectiveness to the principle of non-discrimination. What remained implicit was that in doing so, the national court would have to disapply any other conflicting legal rules, in the concrete case, rules of an international sport association. However, the situation would have been the same had it been the case of national regulation instead. Inasmuch, $\$ 28$ of Walrave and Koch already anticipates Simmenthal 2 , and it does so in a horizontal situation. Therefore, it seems acceptable to contend that, even though Simmenthal 2 was a vertical situation case, the principle which follows from the judgment applies to, both, vertical and horizontal situations alike, at least when it comes to application of the Treaties. In other words, once a rule of national law is contrary to the Treaties, it has to be set aside in either vertical or horizontal situation.

In the case of directives, situation is different. The ECJ hesitated for a long time to extend horizontal direct effects to directives and the question has been explicitly solved in 1994 when the ECJ held that directives may not have horizontal direct effects, i.e. may not create individual rights which national courts must protect in horizontal situations ${ }^{52}$.

While the ECJ was unwilling to recognize horizontal direct effect of directives, it developed auxiliary doctrines ${ }^{53}$ in order to protect effectiveness and uniformity of EU law in national legal orders. When developing those doctrines, the ECJ invested much more interpretative wit then it would have been necessary to justify the horizontal direct effect of directives itself.

In order to remedy the lacking horizontal direct effect, the ECJ has extended the concept of State ${ }^{54}$, elaborated the doctrine of indirect ${ }^{55}$ and incidental effect ${ }^{56}$, recognized State liability for damages on grounds of infringement of EU law ${ }^{57}$ and, finally, recognized exclusionary effects of general principles of law ${ }^{58}$. Not unimportantly, some of the above mentioned doctrines, notably the doctrine of indirect effect, have been introduced in cases concerning incorrect implementation of directives, only to be extended to other sources of EU law.

Notwithstanding the above mentioned developments, application of the Simmenthal mandate in horizontal situations remained controversial. While CIA Security and Unilever advised us that directives may preclude incompatible national law, concerns remained that such exclusionary effects may adversely affect legal

50 Walrave and Koch, above $\mathrm{n} 49$.

51 Walrave and Koch, above n 49, para 28.

52 Faccini Dori v Recreb, above n 13.

53 Or in words of Advocate General Bot, 'palliatives', see Opinion of AG Bot in Case 555/07 Seda Kücükdeveci v Swedex GmbH \& Co. KG. [2010], paras 59-63. However, some authors think that relevance of interpretative effect and Francovich damages reaches beyond what AG Bot calls palliatives. On that point see, T Capeta, Sudovi EU. Nacionalni sudovi kao europski sudovi (Zagreb, IMO, 2002), 59.

54 Case 152/84 M. H. Marshall v Southampton and South-West Hampshire Area Health Authority (Teaching) [1986] ECR 723; Case C-188/89 Foster v British Gas plc [1990] ECR I-3313.

55 Von Colson and Kamman, above $\mathrm{n} 13$.

56 Case C 194/94 CIA Security International [1996] ECR I 2201 and Case C 443/98 Unilever [2000] ECR I 7535.

57 Joined cases C-6/90 and C-9/90 Andrea Francovich and Danila Bonifaci and others $v$ Italian Republic [1991] ECR I-5357; Joined cases C-46/93 and C-48/93 Brasserie du Pêcheur SA v Bundesrepublik Deutschland and The Queen v Secretary of State for Transport, ex parte: Factortame Ltd and others [1996] ECR I1029; Case C-224/01 Gerhard Köbler v Republik Österreich [2003] ECR I-10239.

58 Case C-267/06 Tadao Maruko v Versorgungsanstalt der deutschen Bühnen [2007] ECR I-1757; Case C-144/04 Werner Mangold v Rüdiger Helm [2005] ECR I9981; Case C-427/06 Birgit Bartsch v Bosch und Siemens Hausgeräte (BSH) Altersfürsorge GmbH [2008] ECR I-7245; Case 555/07 Seda Kücükdeveci v Swedex GmbH \& Co. KG. [2010]. 
certainty and legitimate expectations of parties ${ }^{59}$. That issue has been recently questioned by a German court in Kücükdeveci which will be discussed below ${ }^{60}$.

\subsection{Exclusionary effects of EU law}

Once national law can not be stretched by interpretation to be compatible with EU law, it has to be set aside. The question, however, is which legal rule should be applied instead. In order to clarify this issue attempts were made to distinguish between substitutionary and exclusionary effects of EU law ${ }^{61}$. While the former require a clear, unconditional and precise rule of EU law to be applied instead of a rule of national law, exclusionary effects entail setting conflicting national rule aside even in situations where contested rule of EU law is not clear, unconditional and precise $^{62}$.

Exclusionary effect of directives is exemplified by the ECJ judgment in Linster, where the ECJ upheld its well established case law according to which, '... the provisions of the Directive may be taken into account by national courts in order to review whether the national legislature has kept within the limits of the discretion set by i ${ }^{63}$.' More recently in Kücükdeveci, Advocate General Bot relied on this line of case law and observed that exclusionary effect of unimplemented directives prevents application of incompatible national legal rule to the concrete case without application of an clear, unconditional and precise rule of EU law. In such situations a case has to be decided on grounds of national law, '...cleansed of the provisions contrary to the directive ${ }^{64}$.'

It has been contended that the ECJ has never applied provisions of an unimplemented directive to fill gaps in disputes between private parties ${ }^{65}$, and AG Bot pleaded against that course of action, advocating application of cleansed national law ${ }^{66}$. Indeed, in absence of direct effect, i.e. a clear, unconditional and precise rule of EU law, the latter can have only exclusionary and not substitutionary effects. In such situations a case has to be decided on grounds of national law, as interpreted in accordance with EU law.

The described duty of a national judge to set aside a rule of national law even in situations where a rule of EU law leaves a wide discretion to the national authorities, and is not clear, unconditional and precise, is an evidence of separation of Simmenthal mandate from direct effect of EU law.

Another source of EU law which generates exclusionary effects are general principles of EU law, whether those explicitly mentioned by the Treaties (e.g. non-discrimination on grounds of nationality), or articulated by the case law of the ECJ (e.g. State liability for damages for breach of EU law). This can be exemplified by decisions of the ECJ in cases Traghetti del Mediterraneo ${ }^{67}$ and Maruko $^{68}$.

59 For discussion of legal certainty see e.g. P Craig, 'The Legal Effect of Directives: Policy, Rules and Exceptions' (2009) 34 EUR. L. REV. 349 , 353.

60 Seda Kücükdeveci v Swedex GmbH \& Co. KG., above n 53. See A Wiesbrock, 'Case N - Case C-555/07, Kücükdeveci v. Swedex, Judgment of the Court (Grand Chamber) of 19 January 2010' (2010) 11 German Law Journal 539.

61 Dougan, above $\mathrm{n} 48$.

62 This was argued in Case C-287/98 Grand Duchy of Luxemburg v Berthe Linster, Aloyse Linster and Yvonne Linster [2000] ECR I-6917, para 28: ‘The Linsters contend that taking account of an untransposed directive does not necessarily involve an appraisal of its direct effect. Such direct effect is necessary only in order for the directive to have an effect by way of substitution for an existing legal norm. On the other hand, it is the principle of primacy which requires the national court to disapply national legislation contrary to Community law, even where the Community provision at issue lacks direct effect.'

63 Linster, above n 62, para 38.

64 See Opinion of AG Bot in Case 555/07 Seda Kücükdeveci v Swedex GmbH \& Co. KG., above n 53.

65 T Roes, ‘Case C-555/07, Seda Kucukdeveci v. Swedex GmbH \& Co. Kg' (2009-2010) 16 Colum. J. Eur. L. 497, 511.

66 AG Bot in Case 555/07 Seda Kücükdeveci v Swedex GmbH \& Co. KG [2010], para 89 of the Opinion.

67 Traghetti del Mediterraneo SpA $v$ Repubblica italiana, above $\mathrm{n} 46$.

68 Tadao Maruko above n 58, see also Case C 372/04 Watts [2006] ECR I 4325, para 92, and Case C 444/05 Stamatelaki [2007] ECR I 3185 , para 23. 
In Traghetti Italian law limited the State liability for breach of EU law, thus making claims for Francovich damages $^{69}$ virtually impossible. In other words, the issue was whether national rules of civil law can stand in face of a general principle of EU law, which is not directly effective on its own right, which specifies an obligation that '... the Member States are obliged to make good loss and damage caused to individuals by breaches of Community law for which they can be held responsible,' including breaches committed by a national court ${ }^{70}$. In such a situation, a national judge has an obligation to set aside national rule after having performed an analysis of criteria for damages, i.e. after establishing a sufficiently serious breach of EU law which satisfy the Francovich and Brasserie/Factortame II criteria.

Moreover, a national judge has an obligation to set aside a national rule regulating a field which is outside regulatory competences of the EU, such as civil status or social security. In Maruko the ECJ stated that even in exercise of their (exclusive) competences, Member States have to respect principles of EU law ${ }^{72}$. Accordingly, the national legislation running against principle of equality is 'precluded', and it is the duty of national court to set it aside if it finds that there is a difference in treatment in comparable situations.

Admittedly, Maruko is similar to Traghetti inasmuch the two cases concern the duty to set aside a rule of national law on grounds of a general principle of EU law which is either inherent to the Treaties (Traghetti), or occupies a very central position among the values of the EU (Maruko). In the both cases the general principle created exclusionary effects since the rule of EU law was not clear, unconditional and precise.

In its recent case law the ECJ integrated the two streams of its case law previously developed in respect of no horizontal effect of directives and effects of general principles of EU law.

In Kücükdeveci ${ }^{73}$, a preliminary reference from the Landesarbeitsgericht Düsseldorf, the German court questioned whether the principle of legitimate expectations prevents disapplication of a national statutory provision which is facially contrary to EU law ${ }^{74}$.

Kücükdeveci was a horizontal case involving a labour dispute between Swedex $\mathrm{GmbH}$, a private employer, and its employee, Ms. Seda Kücükdeveci. The main issue in the case was whether EU law precludes application of $\S 622$ of the German Civil Code providing that ' $[I] n$ calculating the length of employment, periods prior to the completion of the employee's 25th year of age are not taken into account.' In other words, the question was whether a national court, deciding a horizontal case, has an obligation to set aside a clear provision of national civil code which, for reasons of its clarity, can not be interpreted in accordance with EU law and is, therefore, manifestly contrary to EU law.

69 Francovich, above $\mathrm{n} 57$

70 Francovich, above n 57; Case C-224/01 Gerhard Köbler v Republik Österreich, [2003] ECR I-10239; Joined Cases C-46/93 and C-48/93 Brasserie du Pêcheur and Factortame, above, n 57; Case C-302/97 Konle [1999] ECR I-3099 para 62 and Case C-424/97 Haim [2000] ECR I-5123, para 27.

71 Brasserie du Pêcheur and Factortame, above, $\mathrm{n} 57$.

72 Maruko, above n 59, para 55: '... civil status and the benefits flowing therefrom are matters which fall within the competence of the Member States and Community law does not detract from that competence. However, it must be recalled that in the exercise of that competence the Member States must comply with Community law and, in particular, with the provisions relating to the principle of non-discrimination.'

73 Kücükdeveci, above n 53.

74 The question asked by the German court was: 'In legal proceedings between private individuals, must a court of a Member State disapply a statutory provision which is explicitly contrary to Community law, or is the legitimate expectation of persons subject to the law - that national laws which are in In legal proceedings between private individuals, must a court of a Member State disapply a statutory provision which is explicitly contrary to Community law, or is the legitimate expectation of persons subject to the law - that national laws which are in force will be applied - to be taken into account so that a provision becomes inapplicable only after the Court of Justice has ruled on the disputed provision or a substantially similar provision?'. 
The question reopened the problem of applicability of Simmenthal mandate in horizontal situations. However, the underlying problem was which rule of EU law the national rule encroaches upon - Directive 2000/78/EC of 27 November 2000, the Charter of Rights of the EU, the TFEU, or a general principle of EU law?

The ECJ first reiterated its well established comply or disapply doctrine, according to which, in absence of direct effect, a national court has to interpret national law in accordance with EU law, and that not being possible, has an obligation to set the incompatible rule of national law aside ${ }^{75}$. What is more interesting, in doing so, the ECJ relied on exclusionary effects of general principles of EU law and made clear that general principles of EU law may preclude national legislation that encroaches upon them, and that the Simmenthal mandate applies to such situations ${ }^{76}$. What is even more interesting the case was not decided on grounds of the directive (although the directive was used to bring the case within the scope of EU law), nor on the grounds of the Charter of Rights of the EU, but on grounds of a general principle of non-discrimination which required disapplication of national law.

The judgment in Kücükdeveci shows that an exclusionary dimension of EU law exists in cases where a rule of EU law does not have a direct effect. The ECJ has broadened the principle by telling national courts to ensure '... legal protection which individuals derive from European Union law', in essence, from EU law as interpreted by ECJ, including, but not limited to, general principles of EU law.

The approach undertaken by the ECJ in Kücükdeveci can be compared to the substantive due process doctrine of the Supreme Court of the United States. The Supreme Court extended its jurisdiction to the rule on constitutionality of State statutes on grounds of a general constitutional understanding of liberty. Accordingly, certain fundamental guarantees, such as the XIV. amendment's guarantee of liberty, are protected from exercise of State police powers. This doctrine is exemplified by Griswold v. Connecticut (381 U.S. 479), where the Supreme Court invalidated Connecticut legislation incriminating use of contraceptives. Such arch liberties create penumbras which preclude exercise of State police powers ${ }^{77}$.

Similarity of Griswold and Kücükdeveci is clearly visible. Liberty and equality, respectively, represent original arch liberties that are not constituted but declared by positive law, being it a constitution, a treaty or a directive. In either case, state law has to be set aside. In the both cases jurisdiction of the highest courts is extended to areas that are traditionally considered being a province of individual States. Briefly, general principles of EU law have become consecrated constitutional rules, respect of which has to be ensured by national courts of Member States, subject to supervision of the ECJ.

75 Kücükdeveci, above, n 53, paras 51-55.

76 The ECJ found that the general principle of non-discrimination on grounds of age, 'as given expression by Council Directive 2000/78/EC of 27 November 2000', precludes application of the contested rule.

77 In the words of the Supreme Court, 'The foregoing cases suggest that specific guarantees in the Bill of Rights have penumbras, formed by emanations from those guarantees that help give them life and substance.' And further: 'We deal with a right of privacy older than the Bill of Rights - older than our political parties, older than our school system. Marriage is a coming together for better or for worse, hopefully enduring, and intimate to the degree of being sacred. It is an association that promotes a way of life, not causes; a harmony in living, not political faiths; a bilateral loyalty, not commercial or social projects. Yet it is an association for as noble a purpose as any involved in our prior decisions.' 


\section{Simmenthal and national constitutional review}

Obligation to set aside national legal rules that are in conflict with EU law has strongly empowered judges of national ordinary courts and at the same time disempowered national constitutional courts. One of the victims was their hitherto uncontested right to declare national legislation unconstitutional on grounds of being incompatible with international, or indeed, European law. Understanding that national law which is contrary to international commitments is at the same time unconstitutional for being contrary to Article 11 of the Italian constitution was the rationale of the judgment of the Italian Constitutional Court in decisions that gave rise to the Simmenthal 2 judgment of the ECJ ${ }^{78}$.

A 'new deal' came as a result of the Simmenthal mandate that introduced a system of decentralized constitutional review. In this chapter I will first describe the consequences of decentralized constitutional review and, second, discuss the latest developments that were triggered by the reform of constitutional review in France and their consequences for the Simmenthal mandate.

\subsection{Decentralized system of constitutional review}

One of the often neglected aspects of Simmental 2 is the creation of a decentralized system of constitutional review $^{79}$. The newly acquired powers of a national judge impinge upon powers of national constitutional courts which, in many European States, have a monopoly of deciding constitutional issues and invalidating unconstitutional law. At a closer look Simmenthal 2 has brought European judges closer to their American brothers who, applying the doctrine of judicial review, scrutinize compliance of legislation with the Constitution and '... must, of necessity, expound and interpret' law. Accordingly, '... [i]f two laws conflict with each other, the Courts must decide on the operation of each ${ }^{80}$.'

The logic of Marbury and Simmenthal 2 is strikingly similar. Confronted with two legal rules of different rank, both of them being applicable to the case, the judge deciding the case has to choose between the two, that choice being the essence of judicial duty ${ }^{81}$. The choice does not touch upon the existence of the legal rule which is to be set aside. It only renders it inapplicable in the concrete case.

However, there are important differences between the European and American situation. First and foremost, a number of European states have adopted the Kelsen's model of constitutional review and established strong constitutional courts that are endowed with the monopoly of abstract constitutional review and have a final say when it comes to concrete or accessory constitutional review. Second, while in the United States issues of ordinary and constitutional law are inextricable, the Treaties have established a double-tier system where the

78 Constitution (Italy), Art 11: 'Italy repudiates war as an instrument offending the liberty of the peoples and as a means for settling international disputes; it agrees to limitations of sovereignty where they are necessary to allow for a legal system of peace and justice between nations, provided the principle of reciprocity is guaranteed; it promotes and encourages international organizations furthering such ends.'

79 See e.g. P A Schroth, 'Marbury and Simmenthal: Reflections on the Adoption of Decentralized Judicial Review by the Court of Justice of the European Community’ (1978-1979) 12 Loy. L. A. L. Rev. 869.

80 Marbury v. Madison, 5 U.S. 137, 178.

81 id. '.. if a law be in opposition to the constitution: if both the law and the constitution apply to a particular case, so that the court must either decide that case conformably to the law, disregarding the constitution; or conformably to the constitution, disregarding the law: the court must determine which of these conflicting rules governs the case. This is of the very essence of judicial duty.' 
ECJ has competence for interpretation of EU law, and national courts for interpretation of national law. Accordingly, national constitutional courts maintain the final say in interpretation of national constitutional law.

The described double-tier system has contributed to creation of the judicial dialogue and to the phenomenon that has been described in literature as constitutional pluralism ${ }^{82}$. It is not an overstatement to say that the very emergence of the Simmenthal mandate was triggered by the existence of two tiers of review and, within that context, by the extreme inefficiency of the Italian system of constitutional review according to which there were seven necessary steps to be taken before EU law is applied instead of national legal rule ${ }^{83}$. Inasmuch, it is not surprising that the decentralized constitutional review introduced by Simmenthal 2 was motivated by concern for effectiveness of EU law ${ }^{84}$.

The two tiers of judicial review, of course, do not stand in isolation from one another. In fact, the judicial dialogue that developed between the ECJ and national courts is reflexive. Its reflexivity is manifested by the fact that national and supranational constitutional actors not only act as independent subjects being aware of their powers, but direct their actions towards other actors in attempt to influence and restrict their respective courses of action. We do not speak merely about participation in certain integration processes, but about national actors, primarily the courts, taking an active role in their formation. In other words, their actions are no more inward-oriented but addressed to other participants.

The reflexivity of judicial actions of the high national courts is not only substantive, but also formal and demonstrative. They are not addressed to the narrow professional, or even wider national audiences, but urbi et orbi ${ }^{85}$ in a clear attempt to become persuasive authority within the wider dialogue.

Against the described backdrop it is understandable why Member States which have constitutional courts are better equipped to shape the development of EU law. Being the ultimate protectors of their respective national constitutions they control one of the two tiers of European judicial review. Not less importantly, national constitutional courts have both, authority and voice that can affect shaping of the European legal landscape.

The key challenge that defines the tension between national constitutional courts and the ECJ is the following. If the question of compliance of national law with EU law is a matter of national constitutional law, such as it has been understood by the Italian Corte Costituzionale when interpreting Article 11 of the Italian Constitution, then the issue has to be logically decided by the constitutional court. In such a case, the question of conflict of national law with EU law arises only when an infringement is not detected and eliminated by the constitutional court and, when national court has to apply the law which, despite of having been declared constitutional by the constitutional court, still infringes some rule of EU law. If, on the other hand, the same issue is understood as an issue of application of EU law by a national court, it is for the judge hearing the case to apply EU law directly, taking all consequences of supremacy of EU law into account. The ECJ was clear in that respect. Such situations clearly represent application of EU law and it is for the national

\footnotetext{
82 See e.g. N MacCormick, 'The Maastricht-Urteil: Sovereignty Now' (1995) 1 Eur. L. Journal 259; N MacCormick, Questioning Sovereignty, Law, State and Nation in the European Commonwealth (Oxford, Oxford University Press, 1999); N Walker, 'The Idea of Constitutional Pluralism' (2002) 65 Modern L. Rev. 3, 317; 'Four Visions of Constitutional Pluralism' (2008) EUI Working Paper LAW 2008/21.

83 See Schroth, above, n $79,887$.

84 See e.g. paras 18-22.

85 For example, recent decisions of the Bundesverfassungsgericht and the Czech Constitutional Court in the respective Lisbon Treaty cases were simultaniously published in the national and English language.
} 
judge to disapply all conflicting national legislation, however framed ${ }^{86}$. Moreover, there is no reason why the Variola rationale, according to which Member States have an obligation not to affect the jurisdiction of the ECJ by any national measure ${ }^{87}$, would not also be applicable to the assessment whether certain issue to be decided by a national constitutional court prejudices the jurisdiction of the ECJ. Insofar, saying that an infringement of EU law is at the same time an infringement of the Constitution, can lead a national court to conclude that solving the constitutional issue has priority over application of EU law, in contravention of Variola rule.

\subsection{The Constitutional Challenge}

Emergence of decentralized constitutional review in Simmenthal 2, created an impetus for national constitutional courts to assert their monopoly in issues that, according to their understanding, fall within scope of national constitutional law.

In that context, one of the outstanding problems of the Simmenthal mandate is whether it applies to national constitutional law in the same way as it applies in respect of national ordinary law. The issue has been opened already in the Simmenthal cases since, the Italian Corte Costituzionale considered the issue to be of national constitutional law which, accordingly, had to be settled by Italian constitutional court before an issue of incompatibility with EU law even emerged, and before the ordinary judge was in position to set the national rule aside.

The same issue was hidden behind the second question in Kücükdeveci. The question asked by the German court concerned, on its face, a dilemma whether to set aside the incompatible national rule or to ask the ECJ for a preliminary reference. However, behind that question was another issue, which had been already settled in Simmenthal 2, whether a national constitutional court has a monopoly of declaring national statutes unconstitutional. This aspect of the case is visible from $\S 54$ of the judgment where the ECJ made clear that:

[T] he possibility thus given to the national court by the second paragraph of Article 267 TFEU of asking the Court for a preliminary ruling before disapplying the national provision that is contrary to European Union law cannot, however, be transformed into an obligation because national law does not allow that court to disapply a provision it considers to be contrary to the constitution unless the provision has first been declared unconstitutional by the Constitutional Court ${ }^{88}$.

In other words, prior resolution of a national constitutional issue, prescribed by national law, may not affect the freedom of choice of an ordinary judge whether to disapply the incompatible national rule or address a preliminary reference to the ECJ.

Similar problems of priority emerged recently in France which was, until recently, one of the few European legal systems that was avoiding the Kelsen's model of constitutional review. Within the constitutional system of the $5^{\text {th }}$ Republic, the Conseil Constitutionnel was granted power of a priori constitutional review. This has

86 See e.g. Case C-348/89 Mecanarte - Metalúrgica da Lagoa Lda and Chefe do Serviço de Conferência Final da Alfândega (Head of the Customs Final Verification Department), Oporto [1991] ECR I-03277, para 46.

87 Variola, above $\mathrm{n} 22$ para 11, '... Member States are under an obligation not to introduce any measure which might affect the jurisdiction of the Court to pronounce on any question involving the interpretation of Community law or the validity of an act of the institutions of the Community, which means that no procedure is permissible whereby the Community nature of a legal rule is concealed from those subject to it .'

88

Kücükdeveci, above n 53, para 54. 
changed on March 1 $1^{\text {st }} 2010$, when a major constitutional reform ${ }^{89}$ granted the Conseil power of a posteriori concrete constitutional review upon reference of an ordinary court, bringing the French system in line with the Kelsen's model ${ }^{90}$.

Since March 1, 2010, the French law stands as follows. According to Article 23-1 of the Institutional Act No 2009-1523 which implements Article 61-1 of the Constitution, a national court deciding a case has to, when confronted with issue of compatibility of national law with international commitments entered into by France, refer the issue to the Cour de cassation, or Conseil d'Etat, whichever the case may be. Following the screening, the Cour or the Conseil will institute the priority preliminary reference proceeding before the Conseil Constitutionnel, which will make a decision on conformity of the contested law with the French Constitution. The new French legislation, on its face, may have lead to two consequences, both being suspect from the EU law point of view. First, if the law is declared unconstitutional for being contrary to EU law, the power of an ordinary court judge to disapply it is preempted. Second, an ordinary judge is instructed not to address a preliminary reference to the EJC before the Conseil Constitutionnel has spoken on the matter.

However, the Conseil Constitutionnel, in its decision of May 12, 201091, acting upon priority preliminary reference addressed by the Cour de Cassation, dismissed the above mentioned concerns. The Conseil made clear that commitments under EU law prevail over national law, even in case when the latter has been declared constitutional $^{92}$. The Conseil continued by saing that,

[n] either Article 61-1 of the Constitution nor Articles 23-1 and following of the Ordinance of November 7th 1958 referred to hereinabove preclude a judge, asked to rule in litigation in which the argument of incompatibility with European Union law is raised, from doing, at any time, all and everything necessary to prevent the application in the case in hand of statutory provisions impeding the full effectiveness of the norms and standards of the European Union ${ }^{93}$.

The ECJ had an opportunity to express its opinion on this point in the judgment of the Court (Grand Chamber) of 22 June 2010, in joined cases Aziz Melki and Sélim Abdeli ${ }^{94}$. The matter came before the ECJ as a preliminary reference from the Cour de Cassation, asking whether Article 267 of the TFEU precludes national legislation, such as the French, requiring an ordinary judge to refer the question of constitutionality of a national law on grounds of infringement of EU law, to the Conseil Constitutionne $l^{95}$.

The answer of the ECJ is straightforward and, not surprisingly, builds on its well established case law. The ECJ took effort to explain in great detail what requirements national legislation introducing interlocutory constitutional review has to meet in order to pass the EU muster. As the ECJ clarified in $\$ 57$ of the judgment, Article 267 TFEU precludes national legislation establishing interlocutory constitutional review, insofar that

89 The Reform included an amendment of Art 61-1 of the French Constitution, pursuant to Constitutional Act No 2008-724 of 23 July 2008. The Constitutional amendment was followed by enactment of the Institutional Act No 2009-1523 implementing Art 61-1 of the Constitution.

90 See F Fabbrini, 'Kelsen in Paris: France’s Constitutional Reform and the Introduction of A Posteriori Constitutional Review of Legislation' (2008) 9 German Law Journal 1297

91 Decision n 2010-605 DC of May 12 2010, http://www.conseil-constitutionnel.fr/conseil-constitutionnel/francais/les-decisions/acces-par-date/decisionsdepuis-1959/2010/2010-605-dc/version-en-anglais.48805.html (8 February 2011).

92 id., para 13 of the Decision.

93 id., para 14 of the Decision.

94 Joined cases C-188/10 and C-189/10 Aziz Melki and Sélim Abdeli, judgment of 22 Jun 2010.

95 A similar question has already been addressed to the ECJ from the Belgian Tribunal de première instance de Liège, in Case C-457/09 Chartry which is still pending. 
procedure prevents '... all the other national courts or tribunals from exercising their right or fulfilling their obligation to refer questions to the Court of Justice for a preliminary ruling.'

In any case, national courts deciding the case have to be in position:

- to refer to the Court of Justice for a preliminary ruling, at whatever stage of the proceedings they consider appropriate, even at the end of the interlocutory procedure for the review of constitutionality, any question which they consider necessary,

- to adopt any measure necessary to ensure provisional judicial protection of the rights conferred under the European Union legal order, and

- to disapply, at the end of such an interlocutory procedure, the national legislative provision at issue if they consider it to be contrary to EU law ${ }^{96}$.

Moreover, if national law is challenged before a constitutional court on the same grounds which could challenge validity of a directive which the national law is implementing, the Foto Frost $t^{97}$ principle according to which the ECJ has a monopoly to invalidate secondary EU law has priority ${ }^{98}$ over national interlocutory constitutional review.

The judgment in Melki and Abdeli added an important footnote to the Simmenthal mandate. After essentially having confirmed its position expressed in Factortame $I^{99}$ according to which interim measures aimed at protection of EU law based rights cannot be barred by national constitutional requirements, the ECJ apparently adopted an important concession to national constitutional law. While Simmenthal 2, required the national judge to set aside incompatible national law 'however framed', i.e. including national constitutional law, in Melki and Abdeli it was clarified that the obligation to set aside follows only after a national constitutional court has spoken on the issue, unless the issue of constitutionality is identical to the issue of validity of a rule of EU law that the contested national law purports to implement. In the meantime, a national judge has an obligation to extend interim protection to EU law based individual rights, without an obligation to set suspect national law aside. The important element of the judgment is that after a national constitutional court has spoken, the judge hearing a case still has the Simmenthal obligation to disapply inconsistent national law, even if declared constitutional by the constitutional court.

\section{Conclusions}

Although the Simmenthal mandate, i.e. the obligation of national courts to '... set aside any ${ }^{100}$ provision of national law which may conflict with... [Community law], ... whether prior or subsequent to the Community

96 Melki and Abdeli, above n 94, para 57.

97 Foto-Frost $v$ Hauptzollamt Lübeck-Ost, above $\mathrm{n} 20$.

98 Melki and Abdeli, above n 94, para 56: 'In the case of a national implementing law with such content, the question of whether the directive is valid takes priority, in the light of the obligation to transpose that directive. In addition, imposing a strict time-limit on the examination by the national courts cannot prevent the reference for a preliminary ruling on the validity of the directive in question.' 99 Case C- 213/89 The Queen $v$ Secretary of State for Transport, ex parte: Factortame Ltd and others (Factortame I) [1990] ECR I-2433. The ECJ found that a
common law rule of constitutional nature, according to which an interim relief can not be granted against the Crown, may not stand in way of application of EU law.

100 Emphasis added. 
rule... ${ }^{101}$, established by the ECJ in March 1978, after more then thirty years still stands uncontested in doctrinal terms, its practical application has significantly evolved. That evolution is partly due to the efforts of the ECJ to maintain uniformity and increase effectiveness of EU law, and partly to response of the ECJ to national practices that challenged supremacy of EU law over national constitutional law and national constitutional values.

The transformation of the Simmenthal mandate is characterized by three major developments: evolution of indirect effect doctrine, acceptance of margin of appreciation and expansion of exclusionary effects of EU law. At the same time national reaction was characterized by dualist approach of national constitutional courts and by perseverance with requirements of national constitutional review.

(1) The duty to interpret national law in accordance with EU law increases the effectiveness of EU law but, at the same time, makes the Simmenthal mandate a subsidiary obligation, which takes place only where EU law-friendly interpretation is not possible. The 'comply or disapply' duty has narrowed the scope of Simmenthal mandate, but at the same time increased responsibility of national courts for the application of EU law, thus increasing its effectiveness at source.

(2) On the other hand, national reaction to supremacy challenged the Simmenthal mandate on several fronts.

While in 1964 it appeared clear that in the eyes of the ECJ Costa supremacy entails supremacy over national constitutional law too, that understanding faced national resistance. As a result of that resistance the ECJ resorted to the margin of appreciation doctrine, thus further narrowing the playground for the Simmenthal mandate. En effet, the duty to set aside national legal rule is present only in situations where certain paramount national constitutional choices and values, such as e.g. the right to life or human dignity, are not at stake, and where national law can not be interpreted in accordance with EU law.

Margin of appreciation may take three forms. First, ad hoc margin of appreciation is controlled by the ECJ and, depending on its judgment, varies from case to case. However, the initial judgment is to be made by national courts. Briefly, the margin of appreciation may limit the Simmenthal mandate in two ways. First, where a rule of national law has stricken 'a fair balance' between various fundamental rights that exist within the EU legal order ${ }^{102}$ and, second, even in cases where that is not a case, where importance of national constitutional choice or value justifies departure from EU law rule.

Second, implied margin of appreciation entails situations where, instead of granting an explicit margin of appreciation the ECJ can decide certain situations to fall outside the scope of EU law in which case national law is applicable and the issue of setting it aside does not arise.

Finally, Treaty based margin of appreciation is exemplified by the Irish Protocol to the Maastricht Treaty, and when understood broadly, includes also exemptions from EU law which are entrenched by the Treaty of Lisbon and its protocols. In such cases duty to set aside inconsistent national law clearly does not exist.

(3) While doctrines of indirect effect and margin of appreciation reduced the need for actual recourse to the Simmenthal mandate, the ECJ has significantly extended its scope. Simmenthal 2 concerned an obligation of

101 Simmenthal, above n 2, para 20.

102 See e.g. Case C-275/06 Productores de Música de España (Promusicae) v Telefónica de España SAU [2008] ECR I-271, para 68. 
a Member State under a council regulation. However, the principle itself is applicable to all categories of EU law - directives, the Treaties, and general principles of EU law, and in both, vertical and horizontal situations. Moreover, the exclusionary duty of an ordinary court exists, regardless of whether the rule of EU law is clear, unconditional and precise and regardless of whether the contested national measure is within exclusive competence of Member States. In fact, the breadth of exclusionary effects of EU law seems to depend on the generality of the rule itself. The more general the rule, the broader the scope of its application.

Moreover, in Kücükdeveci the ECJ attributed general principles of EU law significance of a constitutional norm which permeates the entire legal order of the EU, including the legal orders of the Member States ${ }^{103}$.

The judgment in Kücükdeveci is important for one more reason. Recognizing general principles of law exclusionary effects and accepting, in essence, the radiation theory, the ECJ gave preference to uniformity before national understanding of legal certainty ${ }^{104}$. An alternative approach would be to recourse to principles of equivalence and effectiveness, according to which protection of EU law based rights can be State-specific as long as it is equivalent to protection of rights based in national law, and as long as it does not make the exercise of EU law based rights virtually impossible or excessively difficult ${ }^{105}$.

(4) National reaction relied on the obligation of the ECJ under Article 19 of the TEU, to '...ensure that in the interpretation and application of the Treaties the law is observed' creates interpretative dualism where national courts are in charge of interpreting national law and, at the same time, can not themselves, decide on validity of EU law. On the other hand, strictly speaking, the ECJ is constrained within interpretation of EU law and has nothing to say about validity of national law. That being so, the only way for national courts to challenge EU law on grounds of national constitution is to declare a national measure implementing an obligation under EU law unconstitutional. This, however, is subject to additional constraints. Declaring a national implementing measure unconstitutional should follow, only if an interpretation friendly to both, the constitution and EU law is not possible. Second, it should not amount to a breach of bona fide implementation.

(5) The most recent challenge to the Simmenthal mandate comes from national procedural requirements of interlocutory constitutional review. Namely, assertion of the monopoly of national constitutional courts to set national legislation aside for being contrary to EU law has once again questioned the Simmenthal mandate. There seem to be three different situations which govern relationship between national constitutional review and the Simmenthal mandate.

First, in situations which are outside scope of EU law, national rules governing constitutional review apply.

Second, in situations which are within the scope of EU law there are two tiers of review - constitutional review before a constitutional court for interpretation of national law and review before the ECJ for interpretation of EU law. In this type of situations, first of all, obligation of national ordinary courts to refer a preliminary reference to the ECJ is not affected by interlocutory constitutional review. They retain right to refer at any

\footnotetext{
103 The understanding according to which fundamental rights radiate through the entire legal system was developed by the German Constitutional Court in the landmark Lüth decision, BVerfGE 7, 198. See e.g. J Bomhoff, 'Lüth's 50th Anniversary: Some Comparative Observations on the German Foundations of Judicial Balancing' (2008) 9 German Law Journal 121.

104 As Advocate General Kokott rightly observed, the latter approach does not contribute to uniformity of EU law, and puts greater emphasis on national positive law and on the traditional understanding of legal certainty. J Kokott, 'The Basic Law at 60 - From 1949 to 2009 : The Basic Law and Abovenational Integration' (2010) 11 German Law Journal, 99, 112.

105 Joined cases 66, 127 and 128/79 Amministrazione delle Finanze v Srl Meridionale Industria Salumi, Fratelli Vasanelli and Fratelli Ultrocchi [1980] ECR 1237, para 20.
} 
stage of the proceedings and to ensure provisional judicial protection of EU law based rights. As far as their duty to set aside incompatible national law is concerned, the minimum requirement is that a national judge should be in position to do so at least at the end of the interlocutory procedure.

Third, where the issue of validity of secondary EU law and the issue of constitutionality of national law implementing it are identical, two variants have to be distinguished. If validity of EU law is at stake, the Foto Frost principle requires that reference to the ECJ on validity takes precedence over interlocutory constitutional review. Although the ECJ remained silent, it also follows that once declared valid by the ECJ, the contested rule can not be declared invalid on constitutional grounds under the guise of constitutional review.

If, on the other hand, there is a need for interpretation of EU law, parallel interlocutory constitutional review is permissible. National rules regulating interlocutory constitutional review may prevent a judge hearing the case from setting suspect national legislation aside, but must allow a possibility of interim protection of EU law based rights pending the decision of constitutional court.

Apparently, in Melki and Abdeli the ECJ has further narrowed the original definition of Simmenthal mandate by allowing, contrary to what was said in Simmenthal $2^{106}$, national constitutional courts to step in with interlocutory constitutional review. Accordingly, the new formula reads:

[...] and it is not necessary for the court to request or await the prior setting aside of such provision by legislative or other constitutional means, unless required by national rules regulating interlocutory constitutional review, as long as the judge hearing the case can extend interim protection to EU law based rights.

I am not convinced that the new paradigm will improve effectiveness of EU law which was the key concern of the ECJ in Simmenthal 2. It is quite possible, if not likely, that interlocutory constitutional review will become a new battlefront in the European judicial dialogue, prompting the remaining Member States to amend their constitutional systems accordingly. Not to forget, the Treaty of Lisbon has amended Article 10 EC transforming the duty of loyal cooperation, which existed on the side of the Member States, into the duty of sincere cooperation, under Article 4(3) TEU ${ }^{107}$, which is more balanced and imposes the duty of cooperation on the institutions of the EU as well, including within its jurisdiction, the European Court of Justice. The new division of labor between the ECJ and national constitutional courts fits well into that picture, preserving uniformity of EU law, possibly on account of its effectiveness.

\footnotetext{
106 Simmenthal, above n 1, para 24.

107 TFEU, Art 4(3): 'Pursuant to the principle of sincere cooperation, the Union and the Member States shall, in full mutual respect, assist each other in carrying out tasks which flow from the Treaties.'
} 


\section{(1) CEU \\ Instituto Universitario de Estudios Europeos \\ Universidad San Pablo}

\section{Boletín de Suscripción}

Deseo recibir los próximos números de los Documentos de Trabajo de la Serie "Unión Europea" del Instituto Universitario de Estudios Europeos de la Universidad CEU San Pablo:

Nombre y Apellidos

Dirección

Población C.P. País

Teléfono Correo electrónico

Usted tiene derecho a acceder a la información que le concierne, recopilada en nuestro fichero de clientes, y cancelarla o rectificarla en el caso de ser errónea. A través del Instituto Universitario de Estudios Europeos podrá recibir información de su interés. Si no desea recibirla, le rogamos que nos lo haga saber mediante comunicación escrita con todos sus datos.

Si usted está interesado en adquirir ejemplares de alguno de los números ya publicados, sírvase ponerse en contacto con CEU Ediciones:

Teléfono: 915140573

E-mail:publicaciones@ceu.es

Instituto Universitario de Estudios Europeos

Universidad CEU San pablo

Avda. del Valle 21, 28003 Madrid

idee@ceu.es

Teléfono: 915140422 / Fax: 915140428

www.idee.ceu.es 



\section{Números Publicados}

\section{Serie Unión Europea}

No 1 / 2000 "La política monetaria única de la Unión Europea"

Rafael Pampillón Olmedo

No 2 / 2000 "Nacionalismo e integración"

Leonardo Caruana de las Cagigas y Eduardo González Calleja

No 1 / 2001 "Standard and Harmonize: Tax Arbitrage"

Nohemi Boal Velasco y Mariano Gónzalez Sánchez

No 2 / 2001 "Alemania y la ampliación al este: convergencias y divergencias"

José María Beneyto Pérez

No 3 / 2001 "Towards a common European diplomacy? Analysis of the European Parliament resolution on establishing a common diplomacy (A5-0210/2000)"

Belén Becerril Atienza y Gerardo Galeote Quecedo

No 4 / 2001 "La Política de Inmigración en la Unión Europea"

Patricia Argerey Vilar

No 1 / 2002 "ALCA: Adiós al modelo de integración europea?"

Mario Jaramillo Contreras

No 2 / 2002 "La crisis de Oriente Medio: Palestina"

Leonardo Caruana de las Cagigas

№ 3 / 2002 "El establecimiento de una delimitación más precisa de las competencias entre la Unión Europea y los Estados miembros"

José María Beneyto y Claus Giering

No 4 / 2002 "La sociedad anónima europea"

Manuel García Riestra

No 5 / 2002 "Jerarquía y tipología normativa, procesos legislativos y separación de poderes en la Unión Europea: hacia un modelo más claro y transparente"

Alberto Gil Ibáñez

No 6 / 2002 "Análisis de situación y opciones respecto a la posición de las Regiones en el ámbito de la UE. Especial atención al Comité de las Regiones"

Alberto Gil Ibáñez

No 7 / 2002 "Die Festlegung einer genaueren Abgrenzung der Kompetenzen zwischen der Europäischen Union und den Mitgliedstaaten"

José María Beneyto y Claus Giering

No 1 / 2003 "Un español en Europa. Una aproximación a Juan Luis Vives"

José Peña González

No 2/2003 "El mercado del arte y los obstáculos fiscales ¿Una asignatura pendiente en la Unión Europea?"

Pablo Siegrist Ridruejo 
No 1 / 2004 "Evolución en el ámbito del pensamiento de las relaciones España-Europa" José Peña González

No 2 / 2004 "La sociedad europea: un régimen fragmentario con intención armonizadora" Alfonso Martínez Echevarría y García de Dueñas

No 3 / 2004 "Tres operaciones PESD: Bosnia i Herzegovina, Macedonia y República Democrática de Congo" Berta Carrión Ramírez

No 4 / 2004 "Turquía: El largo camino hacia Europa" Delia Contreras

No 5 / 2004 "En el horizonte de la tutela judicial efectiva, el TJCE supera la interpretación restrictiva de la legitimación activa mediante el uso de la cuestión prejudicial y la excepción de ilegalidad" Alfonso Rincón García Loygorri

No 1 / 2005 "The Biret cases: what effects do WTO dispute settlement rulings have in EU law?" Adrian Emch

No 2 / 2005 "Las ofertas públicas de adquisición de títulos desde la perspectiva comunitaria en el marco de la creación de un espacio financiero integrado"

José María Beneyto y José Puente

No 3 / 2005 "Las regiones ultraperiféricas de la UE: evolución de las mismas como consecuencia de las políticas específicas aplicadas. Canarias como ejemplo"

Carlota González Láynez

No 24 / 2006 "El Imperio Otomano: ¿por tercera vez a las puertas de Viena?" Alejandra Arana

No 25 / 2006 "Bioterrorismo: la amenaza latente" Ignacio Ibáñez Ferrándiz

No 26 / 2006 "Inmigración y redefinición de la identidad europea" Diego Acosta Arcarazo

No 27 / 2007 "Procesos de integración en Sudamérica. Un proyecto más ambicioso: la comunidad sudamericana de naciones"

Raquel Turienzo Carracedo

No 28 / 2007 "El poder del derecho en el orden internacional. Estudio crítico de la aplicación de la norma democrática por el Consejo de Seguridad y la Unión Europea”

Gaspar Atienza Becerril

No 29 / 2008 "Iraqi Kurdistan: Past, Present and Future. A look at the history, the contemporary situation and the future for the Kurdish parts of Iraq"

Egil Thorsås

No 30 / 2008 "Los desafíos de la creciente presencia de China en el continente africano".

Marisa Caroço Amaro

No 31 / 2009 "La cooperación al desarrollo: un traje a medida para cada contexto. Las prioridades para la promoción de la buena gobernanza en terceros países: la Unión Europea, los Estados Unidos y la Organización de las Naciones Unidas"

Anne Van Nistelrooij 
No 32 / 2009 "Desafíos y oportunidades en las relaciones entre la Unión Europea y Turquía" Manuela Gambino

No 33 / 2009 "Las relaciones transatlánticas tras la crisis financiera internacional: oportunidades para la Presidencia Española"

Román Escolano

№ 34 / 2010 "Los derechos fundamentales en los tratados europeos. Evolución y situación actual" Silvia Ortiz Herrera

No 35 / 2010 "La Unión Europea ante los retos de la democratización en Cuba" Delia Contreras

No 36 / 2010 "La asociación estratégica UE- Brasil. Retórica y pragmatismo en las relaciones Euro-Brasileñas" (Vol 1 y 2)

Ana Isabel Rodríguez Iglesias

No 37 / 2011 "China's foreign policy: A European perspective"

Fernando Delage y Gracia Abad

No 38 / 2011 "China’s Priorities and Strategy in China-EU Relations"

Chen Zhimin, Dai Bingran, Pan Zhongqi and Ding Chun

No 39 / 2011 "Motor or Brake for European Policies? Germany's new role in the EU after the Lisbon-Judgment of its Federal Constitutional Court"

Ingolf Pernice 



\section{Serie Política de la Competencia}

No 1 / 2001 "El control de concentraciones en España: un nuevo marco legislativo para las empresas" José María Beneyto

No 2 / 2001 "Análisis de los efectos económicos y sobre la competencia de la concentración EndesaIberdrola"

Luis Atienza, Javier de Quinto y Richard Watt

No 3 / 2001 "Empresas en Participación concentrativas y artículo 81 del Tratado CE: Dos años de aplicación del artículo 2(4) del Reglamento CE de control de las operaciones de concentración" Jerónimo Maíllo González-Orús

No 1 / 2002 "Cinco años de aplicación de la Comunicación de 1996 relativa a la no imposición de multas o a la reducción de su importe en los asuntos relacionados con los acuerdos entre empresas" Miguel Ángel Peña Castellot

No 2 / 2002 "Leniency: la política de exoneración del pago de multas en derecho de la competencia" Santiago Illundaín Fontoya

No 3 / 2002 "Dominancia vs. disminución sustancial de la competencia ¿̨uál es el criterio más apropiado?: aspectos jurídicos"

Mercedes García Pérez

No 4 / 2002 "Test de dominancia vs. test de reducción de la competencia: aspectos económicos" Juan Briones Alonso

No 5 / 2002 "Telecomunicaciones en España: situación actual y perspectivas" Bernardo Pérez de León Ponce

No 6 / 2002 "El nuevo marco regulatorio europeo de las telecomunicaciones" Jerónimo González González y Beatriz Sanz Fernández-Vega

No 1 / 2003 "Some Simple Graphical Interpretations of the Herfindahl-Hirshman Index and their Implications" Richard Watt y Javier De Quinto

No 2 / 2003 "La Acción de Oro o las privatizaciones en un Mercado Único"

Pablo Siegrist Ridruejo, Jesús Lavalle Merchán, Emilia Gargallo González

No 3 / 2003 "El control comunitario de concentraciones de empresas y la invocación de intereses nacionales. Crítica del artículo 21.3 del Reglamento 4064/89”

Pablo Berenguer O’Shea y Vanessa Pérez Lamas

No 1 / 2004 "Los puntos de conexión en la Ley 1/2002 de 21 de febrero de coordinación de las competencias del Estado y las Comunidades Autónomas en materia de defensa de la competencia"

Lucana Estévez Mendoza

№ 2 / 2004 "Los impuestos autonómicos sobre los grandes establecimientos comerciales como ayuda de Estado ilícita ex art. 87 TCE"

Francisco Marcos

No 1 / 2005 "Servicios de Interés General y Artículo 86 del Tratado CE: Una Visión Evolutiva" Jerónimo Maillo González-Orús 
No 2 / 2005 "La evaluación de los registros de morosos por el Tribunal de Defensa de la Competencia" Alfonso Rincón García Loygorri

No 3 / 2005 "El código de conducta en materia de fiscalidad de las empresas y su relación con el régimen comunitario de ayudas de Estado"

Alfonso Lamadrid de Pablo

No 18 / 2006 "Régimen sancionador y clemencia: comentarios al título quinto del anteproyecto de la ley de defensa de la competencia"

Miguel Ángel Peña Castellot

No 19 / 2006 "Un nuevo marco institucional en la defensa de la competencia en España" Carlos Padrós Reig

No 20 / 2006 "Las ayudas públicas y la actividad normativa de los poderes públicos en el anteproyecto de ley de defensa de la competencia de 2006”

Juan Arpio Santacruz

№ 21 / 2006 "La intervención del Gobierno en el control de concentraciones económicas" Albert Sánchez Graells

No 22 / 2006 "La descentralización administrativa de la aplicación del Derecho de la competencia en España" José Antonio Rodríguez Miguez

No 23 / 2007 "Aplicación por los jueces nacionales de la legislación en materia de competencia en el Proyecto de Ley"

Juan Manuel Fernández López

No 24 / 2007 "El tratamiento de las restricciones públicas a la competencia" Francisco Marcos Fernández

No 25 / 2008 "Merger Control in the Pharmaceutical Sector and the Innovation Market Assessment. European Analysis in Practice and differences with the American Approach"

Teresa Lorca Morales

No 26 / 2008 "Separación de actividades en el sector eléctrico" Joaquín Ma Nebreda Pérez

No 27 / 2008 "Arbitraje y Defensa de la Competencia"

Antonio Creus Carreras y Josep Maria Julià Insenser

No 28 / 2008 "El procedimiento de control de concentraciones y la supervisión por organismos reguladores de las Ofertas Públicas de Adquisición"

Francisco Marcos Fernández

No 29 / 2009 "Intervención pública en momentos de crisis: el derecho de ayudas de Estado aplicado a la intervención pública directa en las empresas"

Pedro Callol y Jorge Manzarbeitia 


\section{Serie Economía Europea}

No 1 / 2001 "Impacto económico de la inmigración de los Países de Europa Central y Oriental a la Unión Europa"

$\mathrm{M}^{\mathrm{a}}$ del Mar Herrador Morales

No 1 / 2002 "Análisis de la financiación de los Fondos Estructurales en el ámbito de la política regional de la Unión Europea durante el período 1994-1999"

Cristina Isabel Dopacio

No 2 / 2002 "On capital structure in the small and medium enterprises: the spanish case" Francisco Sogorb Mira

No 3 / 2002 "European Union foreign direct investment flows to Mercosur economies: an analysis of the country-of-origin determinants“

Martha Carro Fernández

No 1 / 2004 “Es necesario reformar el Pacto de Estabilidad y Crecimiento?” Ana Cristina Mingorance

No 2 / 2004 "Perspectivas financieras 2007-2013: las nuevas prioridades de la Unión Europea y sus implicaciones en la política regional"

Cristina Serrano Leal, Begoña Montoro de Zulueta y Enrique Viguera Rubio

No 3 / 2004 "Stabilisation Policy in EMU: The Case for More Active Fiscal Policy"

María Jesús Arroyo Fernández y Jorge Uxó González

No 1 / 2005 "La negociación de las perspectivas financieras 2007-2013: Una historia de encuentros y desencuentros"

Cristina Serrano Leal

No 9 / 2006 "La cuestión agrícola en las negociaciones comerciales multilaterales" Ana Fernández-Ardavín Martínez y Ma Ángeles Rodríguez Santos

No 10 / 2007 "El modelo de desarrollo finlandés y su posible adaptación a los países del Este" Zane Butina

No 11 / 2008 "La estrategia de Lisboa como respuesta de la UE a los retos de la globalización y al envejecimiento de su población"

Miguel Moltó Calvo 



\section{Serie del Centro de Estudios de Cooperación al Desarrollo}

No 1 / 2003 "Papel de la UE en las recientes cumbres internacionales" Mónica Goded Salto

No 1 / 2004 "La asociación Euro-Mediterránea: Un instrumento al servicio de la paz y la prosperidad" Jesús Antonio Núñez Villaverde

No 2 / 2004 "La retroalimentación en los sistemas de evaluación. Experiencias en la cooperación al desarrollo“

José María Larrú Ramos

No 3 / 2004 "Migraciones y desarrollo: propuestas institucionales y experiencias prácticas" Carlos Giménez, Alberto Acosta, Jaime Atienza, Gemma Aubarell, Xabier Aragall

No 4 / 2004 “Responsabilidad social corporativa y PYMES"

Amparo Merino de Diego

No 1 / 2005 "La relación ONG-Empresa en el marco de la responsabilidad social de la empresa" Carmen Valor y Amparo Merino

No 1 / 2008 "Dos modalidades de evaluación: evaluaciones de impacto aleatorias y evaluaciones participativas"

José María Larrú Ramos y Jorge Lugrís Llerandi

No 2 / 2008 "A system not fit for purpose?"

Sven Grimm

No 3 / 2008 "El fortalecimiento institucional de la sociedad civil: principal desafío de la cooperación internacional"

Ramón E. Daubón

No 4 / 2009

"La relación entre las instituciones y el desarrollo económico de las naciones"

Pablo Bandeira

No 5 / 2009 "El desarrollo institucional en el contexto de la ineficacia de la ayuda oficial: valoración crítica y propuestas de acción”

Pablo Bandeira

No 6 / 2009 "El fortalecimiento de capacidades y el apoyo al desarrollo desde las bases: la experiencia de la RedEAmérica"

Rodrigo Villar

No 7 / 2009 "Mind the gap: Addressing the "Delivery Challenge" in EC Development Cooperation" Jean Bossuyt

No 8 / 2009 "De la reforma política en nuevas democracias: aspectos sistémicos e institucionales y calidad de la democracia"

Manuel Alcántara Sáez y Fátima García Díez

No 9 / 2009 "Algunas limitaciones metodológicas para analizar la gobernabilidad" Miguel Fernández Trillo-Figueroa 
No 10 / 2009 "Fortalecimiento de la sociedad civil para la acción pública y la gobernanza democrática en contextos de desarrollo"

Gonzalo Delamaza

No 11 / 2010 "La gestión de la información en organizaciones de desarrollo Vol. 1 y Vol. 2" Rodríguez - Ariza Carlos

No 12 / 2010 “¿Más es mejor?”

Larru, José María

No 13 / 2010 "Civil society capacity building: An approach in Uganda"

Groenendijk, Kees 


\section{Serie Arbitraje Internacional y Resolución Alternativa de Controversias}

No 1 / 2007 “Towards a new paradigm in international arbitration. The Town Elder model revisited” David W. Rivkin

No 2 / 2008 “Los árbitros y el poder para dictar condenas no pecuniarias" David Ramos Muñoz

No 3 / 2008 "La lucha contra las prerrogativas estatales en el arbitraje comercial internacional" José Fernando Merino Merchán

No 4 / 2009 "Due process and public policy in the international enforcement of class arbitration awards" Stacie I. Strong

No 5 / 2009 "The permanent court of arbitration and the uncitral arbitration rules: current interaction and future prospectives"

Sarah Grimmer 
Resumen: La sentencia del Tribunal de Justicia en el asunto Simmenthal 2, forma parte de la jurisprudencia clave que contribuyó a definir el proceso de constitucionalización del Derecho comunitario en los años 60 y 70 . Esta importante sentencia ha sido interpretada de manera general como desarrollo del principio de primacía del derecho de la UE. Si bien el principio de primacía no ha cambiado significativamente desde los años 60, y ha sido confirmado por el Tratado de Lisboa, por el contrario el mandato Simmenthal ha sufrido una evolución. Hoy en día, ya no puede ser entendido como una consecuencia del principio de primacía sino como una red finamente tejida de cooperación reflexiva de los tribunales nacionales con el Tribunal de Justicia de la UE. En este artículo se describe cómo el mandato Simmenthal ha sido suavizado, principalmente por el desarrollo de los principios de efecto indirecto y de margen de apreciación. También se analizará la posibilidad de separar el mandato Simmenthal de la doctrina de efecto directo y cuáles son las consecuencias prácticas de tal separación. Por último, este artículo tratará de demostrar cómo el mandato Simmenthal afecta al diálogo judicial europeo y cómo ha reavivado posiblemente la necesidad de revisión constitucional en los Estados miembros.

Palabras clave: Primacía, efecto directo, revisión constitucional, cuestiones prejudiciales, derecho de la UE, efecto de exclusión.

Abstract: The judgment of the European Court of Justice in the Simmenthal 2 case belongs to the line of core constitutional cases that helped to defined the process of constitutionalisation of EU law in the 1960s and 1970s. The case is commonly understood as a functional follow-up to the developing doctrine of supremacy of EU law over national laws of the Member States. While the doctrine of supremacy has not significantly changed since the '60s, and has been upheld by the Treaty of Lisbon, the Simmenthal mandate has evolved. Today, it can no longer be understood as a mere procedural prong of supremacy, but rather as a finely knit web of reflexive cooperation of national courts with the ECJ.

In this paper the author will describe how the Simmenthal mandate has been softened, primarily by development of doctrines of indirect effect and margin of appreciation. Then there will be an analysis of whether the Simmenthal mandate can be separated from the doctrine of direct effect and what the practical consequences of such separation would be. Finally, there will be an attempt to demonstrate how the Simmenthal mandate has affected the European judicial dialogue and possibly triggered a revival of the national constitutional review.

Keywords: Supremacy, direct effect, constitutional review, preliminary references, EU law, exclusionary effect. 